\title{
The Role of N-Acetylcysteine Supplementation on the Oxidative Stress Levels, Genotoxicity and Lineage Commitment Potential of Ex Vivo Murine Haematopoietic Stem/Progenitor Cells
}

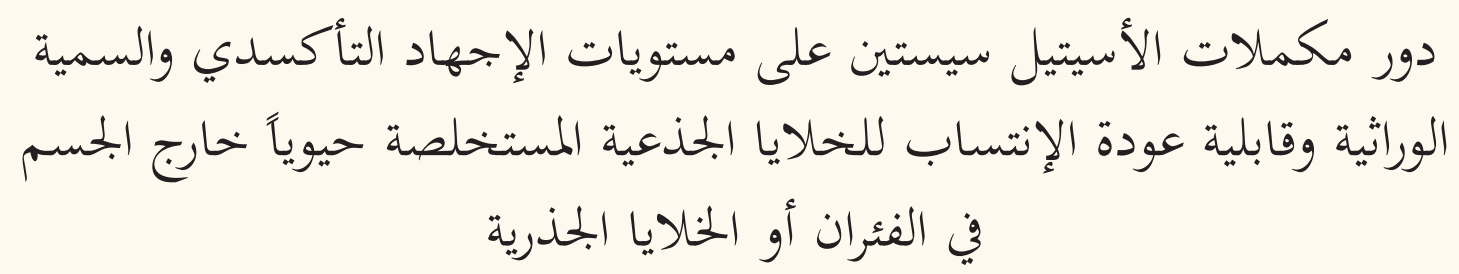

زاريانتي حامد، هيو تان، يايك تشو، خيرو هـارتو، تشن تشان، جمال الدين محمد

ABSTRACT: Objectives: The ex vivo maintenance of haematopoietic stem/progenitor cells (HSPCs) is crucial to ensure a sufficient supply of functional cells for research or therapeutic applications. However, when exposed to reactive oxygen species (ROS) in a normoxic microenvironment, HSPCs exhibit genomic instability which may diminish their quantity and quality. This study aimed to investigate the role of $\mathrm{N}$-acetylcysteine (NAC) supplementation on the oxidative stress levels, genotoxicity and lineage commitment potential of murine haematopoietic stem/progenitor cells (HSPCs). Methods: This study was carried out at the Universiti Kebangsaan Malaysia, Kuala Lumpur, Malaysia, between June 2016 and July 2017. Bone marrow cells were isolated from nine mice and cultured in a growth medium. Various concentrations of NAC between $0.125-2 \mu \mathrm{M}$ were added to the culture for 48 hours; these cells were then compared to non-supplemented cells harvested from the remaining three mice as the control group. A trypan blue exclusion test was performed to determine cell viability, while intracellular ROS levels and genotoxicity were determined by hydroethidine staining and comet assay, respectively. The lineage commitment potential of erythroid, myeloid and pre-B-lymphoid progenitor cells was evaluated via colony-forming cell assay. Results: NAC supplementation at $0.25,0.5$ and $2 \mu \mathrm{M}$ significantly increased cell viability $(P<0.050)$, while intracellular ROS levels significantly decreased at 0.25 and $0.5 \mu \mathrm{M}(P<0.050)$. Moreover, DNA damage was significantly reduced at all NAC concentrations $(P<0.050)$. Finally, the potential lineage commitment of the cells was not significantly affected by NAC supplementation $(P>0.050)$. Conclusion: The findings of this study indicate that NAC supplementation may potentially overcome the therapeutic limitations of ex vivo-maintained HSPCs.

Keywords: Hematopoietic Stem Cells; N-acetylcysteine; Reactive Oxygen Species; DNA Damage; Cell Lineage.

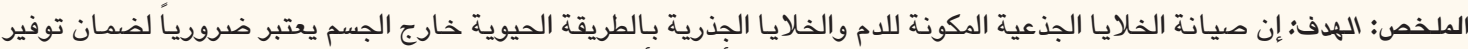

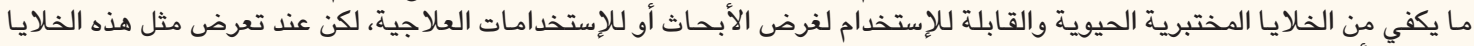

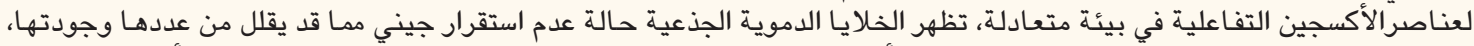

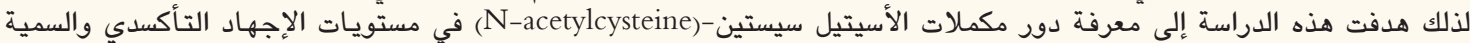

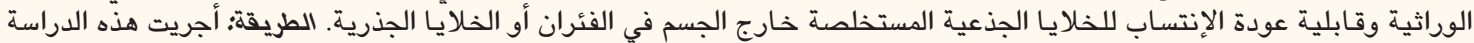

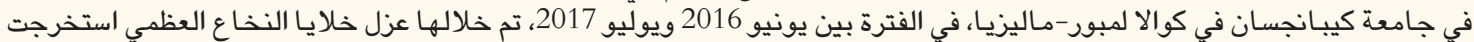

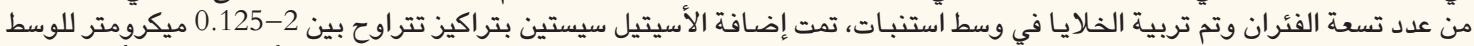

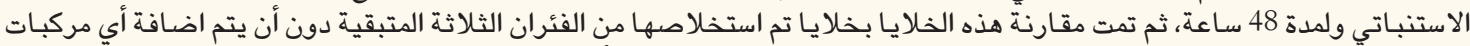

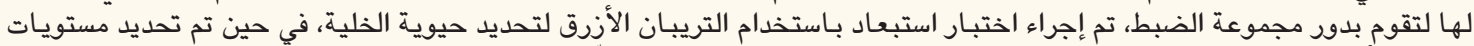

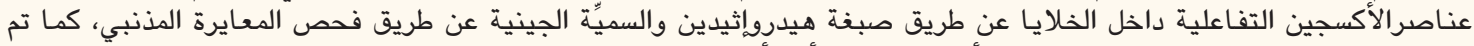

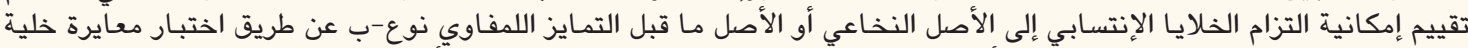

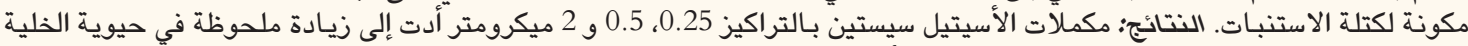

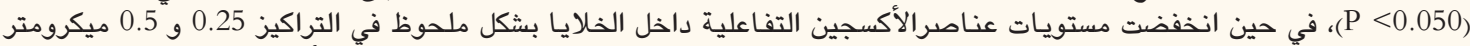

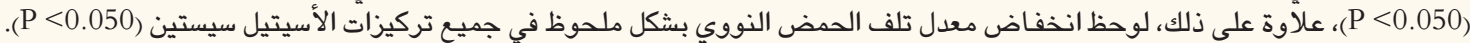

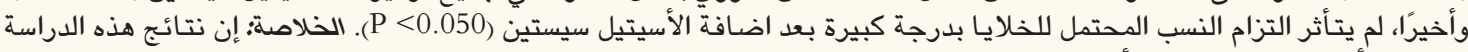

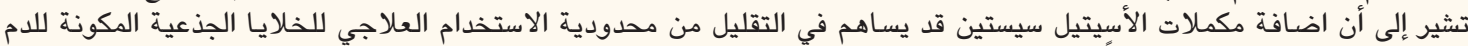

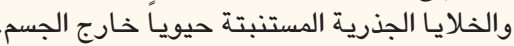

الكلمات المفتاحية؛ الخلايا الجذعية المكونة للدم؛ الأسيتيل سيستين؛ عناصر الاكسجين التفاعلية؛ تلف الحمض النووي؛ انتساب الخلية. 


\section{Advances in KNOWLEdge}

$N$-acetylcysteine (NAC) supplementation may potentially overcome some of the therapeutic limitations associated with the ex vivo expansion and maintenance of haematopoietic stem/progenitor cells (HSPCs).

Specifically, NAC supplementation was found to enhance the survivability of murine HSPCs, while also suppressing reactive oxygen species production and DNA damage and maintaining lineage commitment potential.

\section{Application to Patient Care}

Preservation of the quantity, quality and genomic stability of HSPCS can improve the usefulness of such cells for various medical therapeutic and research applications.

$\mathrm{H}$ AEMATOPOIETIC STEM/PROGENITOR CELLS (HSPCs) constitute a highly promising avenue for medical treatment and research; however, their potency is determined by their ability to selfrenew and differentiate into multiple lineages. ${ }^{1,2}$ Prior to clinical use, stem cells often undergo ex vivo expansion-in which the cells are harvested from an intact organism and directly cultured in a laboratory setting without any biological modification-so as to ensure a sufficient number of functional cells can be harvested. ${ }^{3,4}$ In contrast, in vitro stem cells are obtained from a repository or cell lines that have been genetically transformed.

Physiologically, HSPCs are found in the bone marrow under conditions of low oxygen tension (1-4\%).5,6 This microenvironment is known as a hypoxic niche and plays a critical role in regulating HSPC expansion and cellular levels of reactive oxygen species (ROS). However, the ex vivo expansion and maintenance of HSPCs requires that the cells adjust to normoxic conditions with greater oxygen tension (21\%) and enhanced ROS production. ${ }^{7}$ These conditions can interfere with the self-renewal capacities of HSPCs and promote differentiation, leading to premature senescence and therefore fewer functional stem cells for transplantation., ${ }^{7,8}$ Moreover, excessive ROS production can result in genomic instability, thus compromising the quality of the stem cells and limiting their therapeutic potential. ${ }^{9,10}$ Numerous efforts have been made to overcome the limitations associated with the ex vivo expansion and maintenance of HSPCs, including genetic modification, co-culturing with feeder cells and the addition of a cytokine cocktail; however, these approaches have various drawbacks. ${ }^{11-15}$

Recent research has indicated that the use of antioxidants may be a promising ex vivo expansion technique due to their role as excess ROS scavengers. ${ }^{10,16,17}$ $\mathrm{N}$-acetylcysteine (NAC) is an antioxidant generated from the thiol-containing amino acid cysteine and is the precursor for glutathione. ${ }^{16,18}$ At a concentration of $0.1 \mu \mathrm{M}$, NAC supplementation has been reported to preserve the chromosomal stability of cultured HSPCs. ${ }^{19,20}$ Nonetheless, while previous studies have documented the benefits of NAC supplementation in maintaining haematopoiesis, few have examined their use in the ex vivo maintenance of HSPCs or focused on oxidative-mediated cellular damage and lineage commitment. ${ }^{21,22}$ This study therefore aimed to determine the effect of NAC supplementation on the survivability, DNA integrity, cellular ROS levels and lineage commitment potential of ex vivo HSPCs.

\section{Methods}

This study was carried out at the Universiti Kebangsaan Malaysia, Kuala Lumpur, Malaysia, between June 2016 and July 2017. A total of 12 imprinting control region male mice were included in the study, all of which were 10 weeks old and weighed 30-35 g. Bone marrow cells from three mice were each allocated to an experimental group, while bone marrow cells from the remaining three mice constituted the control group. Each experiment to determine cell viability, cellular ROS production and DNA integrity status was repeated in triplicate using $1 \times 10^{6}$ cells from a different mouse in each group, while $1 \times 10^{6}$ cells were used to determine the lineage commitment potential of erythroid and pre-B lymphoid progenitor cells and $1 \times 10^{5}$ cells were used for myeloid progenitor cells.

Each mouse was killed by cervical dislocation and the tibia and femur were isolated. Pre-cooled Gibco ${ }^{\circledR}$ Dulbecco's Modified Eagle's medium (DMEM; ThermoFisher Scientific, Waltham Massachusetts, USA) was flushed over the bones using a 21 gauge needle and a $10 \mathrm{~mL}$ syringe. Harvested cells were subsequently filtered through a $40 \mu \mathrm{M}$ cell strainer, centrifuged at 2,500 rpm for 7 minutes and resuspended in a growth medium consisting of DMEM supplemented with $10 \%$ fetal bovine serum and $1 \%$ penicillinstreptomycin (ThermoFisher Scientific). A cocktail of growth factors consisting of $100 \mathrm{ng} / \mathrm{mL}$ of stem cell factor, $10 \mathrm{ng} / \mathrm{mL}$ of interleukin (IL) -6 and $5 \mathrm{ng} / \mathrm{mL}$ of IL-3 was then added to the culture (Miltenyi Biotec, Bergisch Gladbach, Germany). Approximately $1 \times 10^{7}$ bone marrow cells were obtained from each mouse. ${ }^{10}$ The cells were then maintained in a $5 \%$ carbon dioxide $\left(\mathrm{CO}_{2}\right)$ incubator at $37{ }^{\circ} \mathrm{C}$ for 24 hours. Subsequently, NAC was added to cells in the experi- 
mental groups at various concentrations $(0.125,0.25$, $0.5,1$ or $2 \mu \mathrm{M})$ for an additional 48 hours. ${ }^{20}$ Cells without NAC supplementation were used as the control group for all parameters. However, an additional positive control group was used to analyse DNA damage, for which the cells received $100 \mu \mathrm{M}$ of hydrogen peroxide for 30 minutes in a $5 \% \mathrm{CO}_{2}$ incubator at $37^{\circ} \mathrm{C}$.

A trypan blue exclusion test was performed to quantify the number of viable cells in samples from both the experimental and control groups. The cells were seeded into 24-well plates containing HSPC growth medium at a density of $1 \times 10^{6}$ cells $/ \mathrm{mL}$. The cell suspension cultures were then diluted at a ratio of 1:1 with $0.4 \%$ trypan blue solution, after which the number of viable cells were counted using a microscope. Cellular ROS production was determined as follows. The cells were harvested and centrifuged at 2,500 rpm for 7 minutes. Approximately $1 \times 10^{6}$ cells were then resuspended in $1 \mathrm{~mL}$ of prewarmed unenriched DMEM medium, stained with $10 \mathrm{mM}$ of hydroethidine (HE; Sigma-Aldrich Corp., St. Louis, Missouri, USA) and incubated in the dark for 30 minutes in a $5 \% \mathrm{CO}_{2}$ incubator at $37{ }^{\circ} \mathrm{C}$. The HE-stained cells were then washed twice and centrifuged at 2,500 rpm for 5 minutes at $4{ }^{\circ} \mathrm{C}$. The supernatant was discarded and the cell pellets resuspended in $500 \mu \mathrm{L}$ of cold phosphate-buffered saline (PBS). ${ }^{10}$ Subsequently, the intensity of HE fluorescence was measured using the BD FACSCanto ${ }^{\mathrm{TM}}$ II flow cytometry system (BD Biosciences, San Jose, California, USA), with ROS production expressed as the percentage of ROS-producing cells.

The potentially genotoxic effect of NAC supplementation was assessed via alkaline comet assay using microgel electrophoresis. ${ }^{23}$ This technique was employed due to its improved detection sensitivity in comparison to direct quantification methods which do not supply current or voltage after the unwinding and neutralisation of the DNA. ${ }^{23,24} \mathrm{~A}$ total of $1 \times 10^{6} / \mathrm{mL}$ of cells from each group were harvested and centrifuged at 2,500 rpm for 5 minutes at $4{ }^{\circ} \mathrm{C}$. The cells were then washed twice in a calcium- and magnesium-free PBS and recentrifuged at $1,200 \mathrm{rpm}$ for 5 minutes at $4{ }^{\circ} \mathrm{C}$. The cell pellets were mixed with $70 \mu \mathrm{L}$ of $0.6 \%$ normal melting point agarose (NMPA) gel (Sigma-Aldrich Corp.). The mixture was loaded onto a full-frosted microscope slide, topped with a coverslip and left to cool on ice for 15 minutes. Once the gel had solidified, the coverslip was gently removed and a layer of $80 \mu \mathrm{L}$ of low melting point agarose gel (Sigma-Aldrich Corp.) was added on top of the NMPA layer. Next, the solidified slide was immersed overnight into a lysis buffer consisting of $2.5 \mathrm{M}$ of sodium chloride, $100 \mathrm{mM}$ of disodium ethylenediaminetetraacetic acid, $10 \mathrm{mM}$ of tris(hydroxymethyl)aminomethane and $1 \%$ Triton $^{\mathrm{TM}}$
X-100 (Sigma-Aldrich Corp.) at $4{ }^{\circ} \mathrm{C}$. The slides were then equilibrated in an electrophoresis buffer at $300 \mathrm{~mA}$ for 20 minutes and then $25 \mathrm{~V}$ for 20 minutes, before being rinsed three times in a neutralisation buffer for 5 minutes each rinse. Thereafter, the slides were stained with $25 \mu \mathrm{L}$ of ethidium bromide (ThermoFisher Scientific) at $20 \mu \mathrm{g} / \mathrm{mL}$ and viewed under a Leica fluorescence microscope (Meyers Instruments, Houston, Texas, USA) using a $590 \mathrm{~nm}$ excitation filter. The amount of DNA in the tail and the tail moment of 100 cells per slide was subsequently analysed using CometScore software (TriTek Technologies Inc., Annandale, Virginia, USA).

The lineage commitment potential of the erythroid, myeloid and lymphoid progenitor cells was determined via colony-forming cell assay using three types of methylcelluloses (MethoCult ${ }^{\mathrm{TM}}$ GF M3334, GF M3534 and M3630, STEMCELL ${ }^{\mathrm{TM}}$ Technologies Inc., Vancouver, Canada). These methylcelluloses were used to support the growth of colony-forming unit (CFU)erythroid, CFU-granulocytes (G), CFU-macrophages (M), CFU-GM and CFU-lymphoid (CFU-pre-B) cells. Myeloid progenitor cells were classified as CFU-G, CFU-M or CFU-GM, based on a morphological analysis of the colonies derived from the assay. The plating density was optimised at $2 \times 10^{5}$ cells $/ \mathrm{mL}$ for CFUGM, $1 \times 10^{6}$ cells $/ \mathrm{mL}$ for CFU-E and $1 \times 10^{6}$ cells $/ \mathrm{mL}$ for CFU-pre-B. The cell and methylcellulose mixture was then placed into a six-well plate and incubated at $37{ }^{\circ} \mathrm{C}$ for either seven (for CFU-E and CFU-pre-B) or 14 (for CFU-GM) days. The number of colonies was then determined via light microscope observation.

Statistical analysis was conducted using the Statistical Package for the Social Sciences (SPSS), Version 22.0 (IBM Corp., Armonk, New York, USA). The results were presented as means \pm standard error and displayed graphically in the form of histograms or plot diagrams. A $P$ value of $<0.050$ was considered statistically significant. A Shapiro-Wilk test was conducted to determine the normality of the data. Where the assumption of normality was not rejected, an independent Student's t-test was employed to test the differences in studied parameters between NAC-supplemented and control cell groups.

All procedures involving the use of laboratory animals in this study were reviewed and approved by the Animal Ethics Committee of the Universiti Kebangsaan Malaysia (\#FSK/2016/ZARIYANTEY/27-JULY/ 773-JULY-2016-JUNE-2017-AR-CAT2).

\section{Results}

In terms of cell viability, there were significantly more viable cells noted among HSPCs supplemented with 


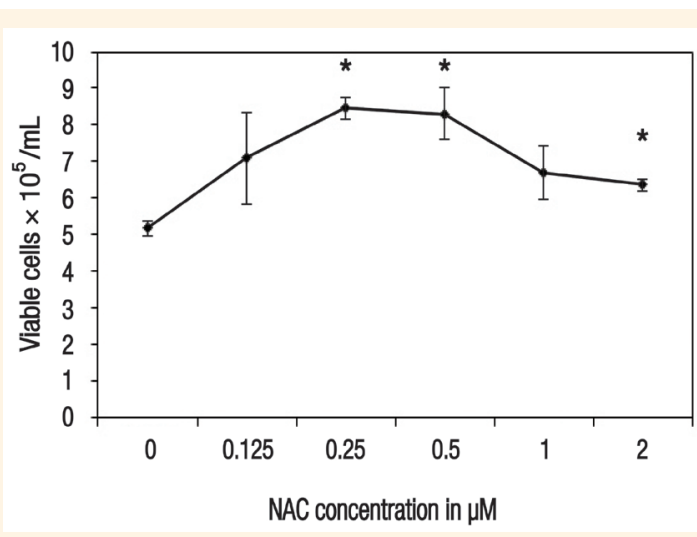

Figure 1: Plot diagram showing the effect of 48-hour $\mathrm{N}$-acetylcysteine (NAC) supplementation on the viability of ex vivo haematopoietic stem/progenitor cells. All values represent means \pm standard error.

$N A C=N$-acetylcysteine.

"Significant difference in comparison to the control group $(P<0.050)$.

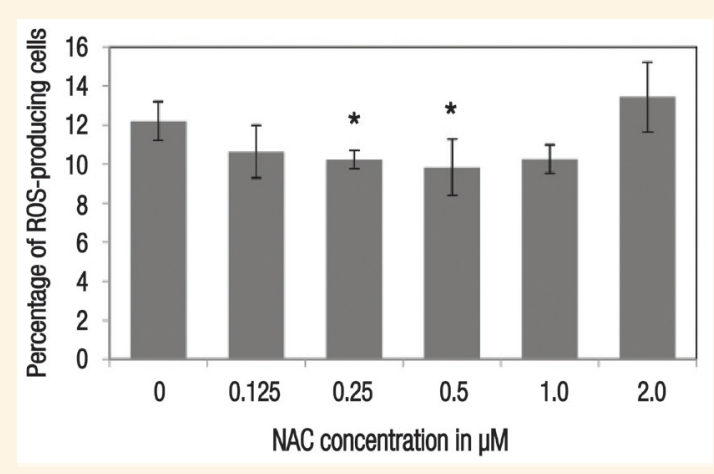

Figure 2: Histogram showing the effect of 48-hour $\mathrm{N}$-acetylcysteine supplementation on the level of reactive oxygen species in ex vivo haematopoietic stem/progenitor cells. All values represent means \pm standard error. $R O S=$ reactive oxygen species; $N A C=N$-acetylcysteine.

"Significant difference in comparison to the control group $(P<0.050)$.
$0.25 \mu \mathrm{M}\left(8.47 \pm 0.29 \times 10^{5}\right.$ cells $\left./ \mathrm{mL} ; P=0.001\right), 0.5 \mu \mathrm{M}$ $\left(8.32 \pm 0.72 \times 10^{5}\right.$ cells $\left./ \mathrm{mL} ; P=0.014\right)$ and $2 \mu \mathrm{M}(6.37$ $\pm 0.16 \times 10^{5}$ cells $\left./ \mathrm{mL} ; P=0.011\right)$ of NAC in comparison to the control group $\left(5.18 \pm 0.20 \times 10^{5}\right.$ cells $\left./ \mathrm{mL}\right)$ [Figure 1]. Cellular ROS production was also significantly lower among cells supplemented with $0.25 \mu \mathrm{M}$ $(10.23 \pm 0.47 \% ; P=0.011)$ and $0.5 \mu \mathrm{M}(9.83 \pm 1.43 \%$; $P=0.040)$ of NAC, as compared to the control group $(12.20 \pm 1.01 \%)$ [Figure 2].

Among NAC-supplemented cells, DNA damage was significantly suppressed, with the percentage of DNA in the tail being $7.65 \pm 0.40 \%(P=0.048), 6.89$ $\pm 0.08 \%(P=0.022)$ and $5.96 \pm 0.98 \%(P=0.027)$ for concentrations of $0.25,0.5$ and $2 \mu \mathrm{M}$ of NAC, respectively, in comparison to the control group $(11.08 \pm 1.15 \%)$ [Figure 3A]. In addition, there was also a significant reduction in the tail moment of NAC-supplemented cells at concentrations of $0.25 \mu \mathrm{M}$ (0.65 \pm 0.06 arbitrary units [AUs]; $P=0.002), 0.5 \mu \mathrm{M}$ $(0.71 \pm 0.12$ AUs; $P=0.003)$ and $2 \mu \mathrm{M}(0.34 \pm 0.03$ AUs; $P=0.001)$, as compared to the control group $(2.04 \pm 0.10$ AUs) [Figure 3B].

Regarding the effect of NAC supplementation on the lineage commitment potential of erythroid, lymphoid and myeloid progenitor cells, there was no significant difference in colony count for CFU-GM at $0.25 \mu \mathrm{M}\left(82.67 \pm 11.05 \times 10^{5}\right.$ cells $\left./ \mathrm{mL} ; P=0.075\right), 0.5 \mu \mathrm{M}$ $\left(77.00 \pm 12.74 \times 10^{5}\right.$ cells $\left./ \mathrm{mL} ; P=0.063\right)$ and $2 \mu \mathrm{M}$ $\left(69.33 \pm 18.67 \times 10^{5}\right.$ cells $\left./ \mathrm{mL} ; P=0.072\right)$ of NAC supplementation, in comparison to the control group (128.67 $\pm 15.76 \times 10^{5}$ cells $/ \mathrm{mL}$ ). For CFU-G, the control group again demonstrated the highest number of colonies $\left(61.67 \pm 7.88 \times 10^{5}\right.$ cells $\left./ \mathrm{mL}\right)$; however, this difference was not significant in comparison to cells supplemented with $0.25 \mu \mathrm{M}\left(36.00 \pm 9.64 \times 10^{5}\right.$ cells $\left./ \mathrm{mL} ; P=0.108\right)$,
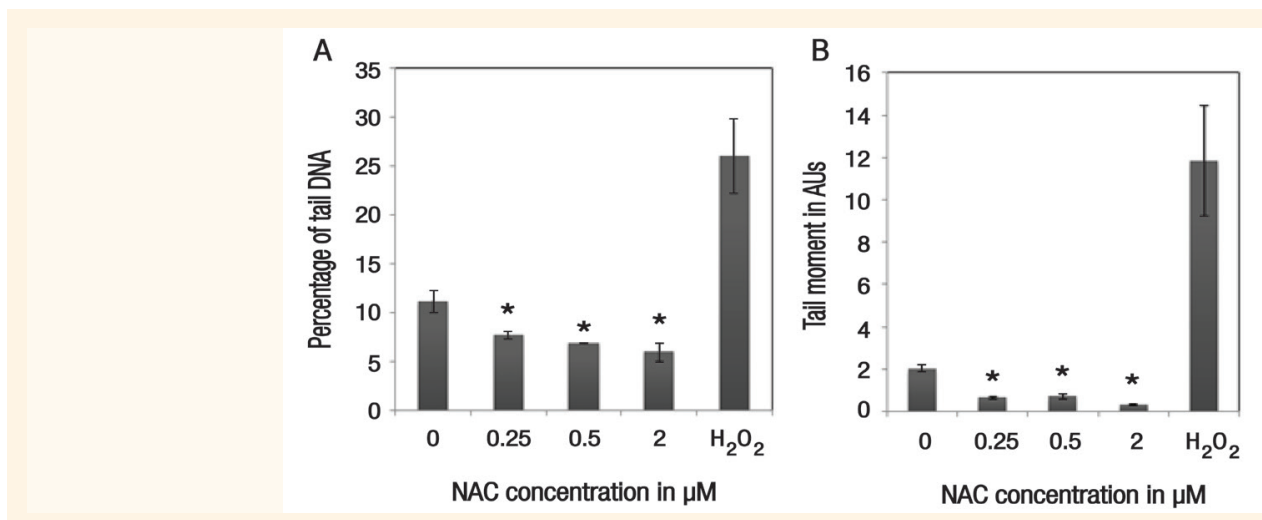

Figure 3: Histograms showing the effect of 48-hour N-acetylcysteine (NAC) supplementation on (A) the percentage of tail DNA and (B) the tail moment of ex vivo haematopoietic stem/progenitor cells. Cells treated with $100 \mu \mathrm{M}$ of hydrogen peroxide served as a positive control group for the purposes of assay validation. All values represent means \pm standard error.

$\mathrm{H}_{2} \mathrm{O}_{2}=$ hydrogen peroxide; $N A C=N$-acetylcysteine; $A U$ S = arbitrary units.

"Significant difference in comparison to the control group $(P<0.050)$. 
A

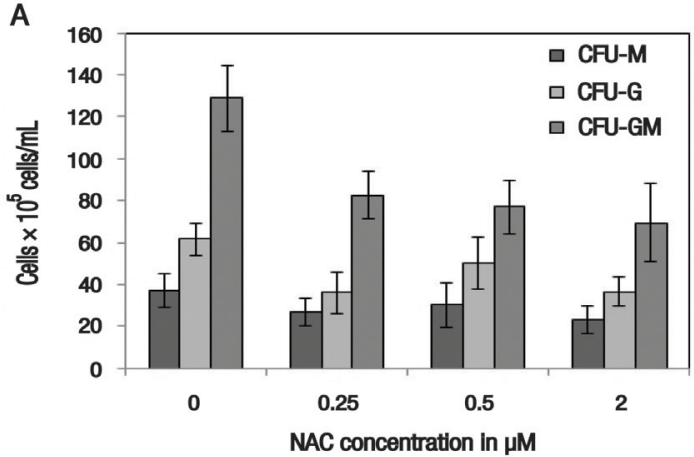

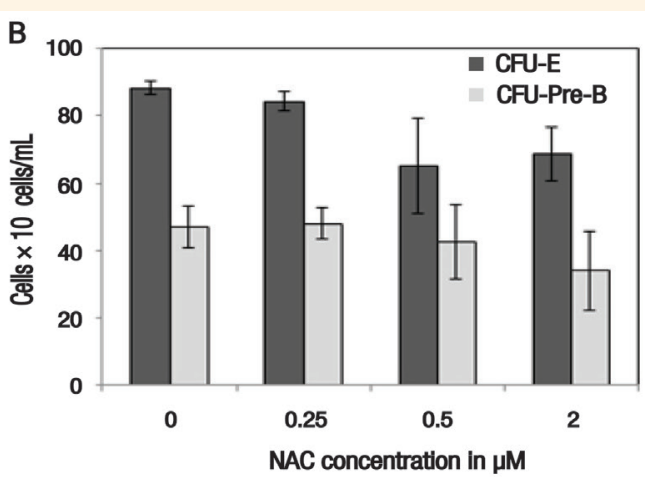

Figure 4: Histograms showing the effect of 48-hour $\mathrm{N}$-acetylcysteine supplementation on the lineage commitment potential of ex vivo haematopoietic stem/progenitor cells. All values represent means \pm standard error. $C F U=$ colony-forming unit; $M=$ macrophages; $G$ = granulocytes; $E=$ erythroid; Pre- $B=$ lymphoid; $N A C=N$-acetylcysteine.

$0.5 \mu \mathrm{M}\left(50.33 \pm 12.60 \times 10^{5}\right.$ cells $\left./ \mathrm{mL} ; P=0.393\right)$ or $2 \mu \mathrm{M}\left(36.67 \pm 6.69 \times 10^{5}\right.$ cells $\left./ \mathrm{mL} ; P=0.073\right)$ of NAC. Similar results were noted for CFU-M, with the highest colony count identified in the control group (37.00 \pm $7.81 \times 10^{5}$ cells $\left./ \mathrm{mL}\right)$, followed by cells supplemented with $0.5 \mu \mathrm{M}\left(30.33 \pm 10.41 \times 10^{5}\right.$ cells $\left./ \mathrm{mL} ; P=0.636\right)$, $0.25 \mu \mathrm{M}\left(27.00 \pm 6.56 \times 10^{5}\right.$ cells $\left./ \mathrm{mL} ; P=0.382\right)$ and $2 \mu \mathrm{M}\left(23.33 \pm 6.44 \times 10^{5}\right.$ cells $\left./ \mathrm{mL} ; P=0.248\right)$ and of NAC [Figure 4A].

Similarly, no significant differences in CFU-E counts were noted between NAC-supplemented cells at $0.25 \mu \mathrm{M}\left(84.30 \pm 2.91 \times 10^{6}\right.$ cells $\left./ \mathrm{mL} ; P=0.330\right)$, $0.5 \mu \mathrm{M}\left(65.00 \pm 14.11 \times 10^{6}\right.$ cells $\left./ \mathrm{mL} ; P=0.177\right)$ and $2 \mu \mathrm{M}\left(68.7 \pm 7.84 \times 10^{6} \mathrm{cells} / \mathrm{mL} ; P=0.073\right)$ and those in the control group $\left(88.30 \pm 2.19 \times 10^{6}\right.$ cells $\left./ \mathrm{mL}\right)$. The colony counts for CFU-pre-B also showed no significant difference between the control group (47.00 \pm $6.08 \times 10^{6} \mathrm{cells} / \mathrm{mL}$ ) and the NAC-supplemented cells at concentrations of $0.25 \mu \mathrm{M}\left(48.00 \pm 4.58 \times 10^{6}\right.$ cells $/ \mathrm{mL}$; $P=0.902), 0.5 \mu \mathrm{M}\left(42.67 \pm 11.05 \times 10^{5}\right.$ cells $\left./ \mathrm{mL} ; P=0.748\right)$ and $2 \mu \mathrm{M}\left(34.00 \pm 11.68 \times 10^{6}\right.$ cells $\left./ \mathrm{mL} ; P=0.379\right)$ [Figure 4B].

\section{Discussion}

Maintenance of ROS production at optimum levels is crucial to regulate the intracellular and extracellular signalling pathways involved in the self-renewal and differentiation activities of HSPCs. ${ }^{5,25}$ Excessive levels of ROS can trigger cells to undergo differentiation rather than self-renewal, while too few ROS can inhibit proliferation..$^{26}$ The production of ROS is closely related to cellular respiration among metabolically inactive HSPCs in a dormant state. ${ }^{6-8}$ Inversely, when HSPCs are placed under stress, such as in normoxic conditions, mitochondrial activities are elevated and contribute to elevated ROS production. ${ }^{5,27}$ Previous studies have reported that altering the microenvironment of HSPCs to normoxic conditions can lead to a reduction in the number of
HSPCs due to an increase in differentiation, premature ageing and apoptosis. ${ }^{7,28}$

In the current study, NAC supplementation was found to enhance the survivability of HSPCs at specific concentrations $(0.25,0.5$ and $2 \mu \mathrm{M})$. Moreover, HSPCs which did not receive NAC supplementation showed the lowest cell viability. This finding is in accordance with a previous study which reported the beneficial effects of NAC in minimising cytotoxicity among irradiated rat bone marrow cells by improving the mitotic index.22 Moreover, the current study found that NAC supplementation at concentrations of 0.25 and $0.5 \mu \mathrm{M}$ suppressed cellular ROS levels; this finding is in agreement with those of a previous study. ${ }^{5}$ Altinoz et al. also demonstrated the protective role of NAC against acrylamide-induced oxidative stress in rats. ${ }^{29}$ It can therefore be postulated that optimum ROS levels play a role in promoting survivability and maintenance in HSPCs.

Increased ROS production can overload the cellular antioxidant capacity, exposing macromolecules such as DNA, ribonucleic acid and proteins to ROS attack. ${ }^{30}$ This can lead to the accumulation of DNA damage and premature cell ageing during long-term culturing. ${ }^{26}$ In the present study, NAC supplementation was found to have a genoprotective function, as evidenced by the remarkably low levels of DNA damage observed in NAC-supplemented cells as compared to those in the control group. Other studies have reported that NAC has the ability to reverse DNA damage in rat models with irradiated bone marrow, hepatopulmonary syndrome and acrylamide-induced genotoxicity. ${ }^{21,22,29}$

The current study also investigated the effects of NAC supplementation on the lineage commitment potential of erythroid, myeloid and lymphoid progenitor cells and found that NAC supplementation did not affect the lineage commitment potential of these respective progenitors. To the best of the authors' knowledge, no previous studies have been conducted 
to assess the lineage commitment potential among NAC-supplemented ex vivo HSPCs. However, a previous study reported that the administration of $100 \mu \mathrm{M}$ of NAC for four weeks in mice enhanced the repopulation of myeloid progenitors, as evidenced by increased colony counts. ${ }^{31}$

As previously discussed, HSPCs are at greater risk of oxidative stress exposure following ex vivo maintenance, a factor which can impair their usefulness in terms of both quality and quantity. ${ }^{7-10}$ Overall, the results of the present study indicate that NAC may have a potential role as an antioxidant supplement for the optimal expansion and maintenance of HSPCs, without compromising their potential for self-renewal and multilineage differentiation. However, further research is necessary to support these findings, especially considering the small sample size of the current study necessitated by financial constraints and the short study duration. Nevertheless, despite these limitations, these findings may serve as a platform for future research exploring the use of antioxidants in HSPC expansion and maintenance.

\section{Conclusion}

The findings of this study support the use of NAC supplementation for the ex vivo maintenance of HSPCs by reducing oxidative stress and maintaining their selfrenewal and multilineage differentiation properties without genotoxic effects. However, further research with a larger sample size is needed to investigate the role of NAC supplementation on the oxidative status and genomic stability of HSPCs following long-term ex vivo maintenance.

\section{CONFLICT OF INTEREST}

The authors declare no conflicts of interest.

\section{FUNDING}

This study was funded with the aid of a grant from the Ministry of Higher Education in Malaysia (grant \#FRGS/1/2016/SKK13/UKM/03/1).

\section{References}

1. Doulatov S, Notta F, Laurenti E, Dick JE. Hematopoiesis: A human perspective. Cell Stem Cell 2012; 10:120-36. doi: 10. 1016/j.stem.2012.01.006

2. Boisset JC, Robin C. On the origin of hematopoietic stem cells: Progress and controversy. Stem Cell Res 2012; 8:1-13. doi: 10.1016/j.scr.2011.07.002.

3. Dahlberg A, Delaney C, Bernstein ID. Ex vivo expansion of human hematopoietic stem and progenitor cells. Blood 2011; 117:6083-90. doi: 10.1182/blood-2011-01-283606.
4. Bird GA, Polsky A, Estes P, Hanlon T, Hamilton H, Morton JJ, et al. Expansion of human and murine hematopoietic stem and progenitor cells ex vivo without genetic modification using MYC and Bcl-2 fusion proteins. PLoS One 2014; 9:e105525. doi: 10.1371/journal.pone.0105525.

5. Ludin A, Gur-Cohen S, Golan K, Kaufmann KB, Itkin T, Medaglia C et al. Reactive oxygen species regulate hematopoietic stem cell self-renewal, migration and development, as well as their bone marrow microenvironment. Antioxid Redox Signal 2014; 21:1605-19. doi: 10.1089/ars.2014.5941.

6. Mantel CR, O'Leary HA, Chitteti BR, Huang X, Cooper S, Hangoc G, et al. Enhancing hematopoietic stem cell transplantation efficacy by mitigating oxygen shock. Cell 2015; 161:1553-65. doi: 10.1016/j.cell.2015.04.054

7. Broxmeyer HE, O'Leary HA, Huang X, Mantel C. The importance of hypoxia and extra physiologic oxygen shock/ stress for collection and processing of stem and progenitor cells to understand true physiology/pathology of these cells exvivo. Curr Opin Hematol 2015; 22:273-8. doi: 10.1097/MOH. 0000000000000144.

8. Shao L, Li H, Pazhanisamy SK, Meng A, Wang Y, Zhou D. Reactive oxygen species and hematopoietic stem cell senescence. Int J Hematol 2011; 94:24-32. doi: 10.1007/s12185-0110872-1.

9. Mohyeldin A, Garzón-Muvdi T, Quiñones-Hinojosa A. Oxygen in stem cell biology: A critical component of the stem cell niche. Cell Stem Cell 2010; 7:150-61. doi: 10.1016/j.stem.2010.07.007.

10. Abdul Hamid Z, Lin Lin WH, Abdalla BJ, Bee Yuen O, Latif ES, Mohamed J, et al. The role of Hibiscus sabdariffa L. (Roselle) in maintenance of ex vivo murine bone marrow-derived hematopoietic stem cells. ScientificWorldJournal 2014; 2014:258192. doi: 10.1155/2014/258192.

11. Lee J, Shieh JH, Zhang J, Liu L, Zhang Y, Eom JY, et al. Improved ex vivo expansion of adult hematopoietic stem cells by overcoming CUL4-mediated degradation of HOXB4. Blood 2013; 121:4082-9. doi: 10.1182/blood-2012-09-455204.

12. Amsellem S, Pflumio F, Bardinet D, Izac B, Charneau P, Romeo PH, et al. Ex vivo expansion of human hematopoietic stem cells by direct delivery of the HOXB4 homeoprotein. Nat Med 2003; 9:1423-7. doi: 10.1038/nm953.

13. Ren Z, Jiang Y. Umbilical cord blood hematopoietic stem cell expansion ex vivo. J Blood Disord Transfus 2013; S3:004. doi: 10.4172/2155-9864.S3-004.

14. Takagi M. Cell processing engineering for ex-vivo expansion of hematopoietic cells. J Biosci Bioeng 2005; 99:189-96. doi: 10.12 63/jbb.99.189.

15. Watts KL, Adair J, Kiem HP. Hematopoietic stem cell expansion and gene therapy. Cytotherapy 2011; 13:1164-71. doi: 10.3109/ 14653249.2011.620748.

16. Berniakovich I, Laricchia-Robbio L, Izpisua Belmonte JC. $\mathrm{N}$-acetylcysteine protects induced pluripotent stem cells from in vitro stress: Impact on differentiation outcome. Int J Dev Biol 2012; 56:729-35. doi: 10.1387/ijdb.120070ji.

17. Luo L, Kawakatsu M, Guo CW, Urata Y, Huang WJ, Ali H, et al. Effects of antioxidants on the quality and genomic stability of induced pluripotent stem cells. Sci Rep 2014; 4:3779. doi: $10.1038 /$ srep03779.

18. Moslehi A, Taghizadeh-Ghehi M, Gholami K, Hadjibabaie M, Jahangard-Rafsanjani Z, Sarayani A, et al. N-acetyl cysteine for prevention of oral mucositis in hematopoietic SCT: A doubleblind, randomized, placebo-controlled trial. Bone Marrow Transplant 2014; 49:818-23. doi: 10.1038/bmt.2014.34.

19. Hu L, Cheng H, Gao Y, Shi M, Liu Y, Hu Z, et al. Antioxidant $\mathrm{N}$-acetyl-L-cysteine increases engraftment of human hematopoietic stem cells in immune-deficient mice. Blood 2014; 124:e45-8. doi: 10.1182/blood-2014-03-559369. 
20. Liu AM, Qu WW, Liu X, Qu CK. Chromosomal instability in in vitro cultured mouse hematopoietic cells associated with oxidative stress. Am J Blood Res 2012; 2:71-6.

21. Vercelino R, Tieppo J, Dias AS, Marroni CA, Garcia E, Meurer L, et al. $\mathrm{N}$-acetylcysteine effects on genotoxic and oxidative stress parameters in cirrhotic rats with hepatopulmonary syndrome. Basic Clin Pharmacol Toxicol 2008; 102:370-6. doi: 10.1111/j. 1742-7843.2007.00181.x

22. Demirel C, Kilçiksiz S, Ay OI, Gürgül S, Ay ME, Erdal N. Effect of $\mathrm{N}$-acetylcysteine on radiation-induced genotoxicity and cytotoxicity in rat bone marrow. J Radiat Res 2009; 50:43-50. doi: 10.1269/jrr.08066.

23. Singh NP, McCoy MT, Tice RR, Schneider EL. A simple technique for quantification of low levels of DNA damage in individual cells. Exp Cell Res 1988; 175:184-91. doi: 10.1016/ 0014-4827(88)90265-0.

24. Rydberg B, Johanson KJ. Estimation of DNA strand breaks in single mammalian cells. In: Hanawalt PC, Fox CF, Friedberg EC, Eds. DNA Repair Mechanisms, 1st ed. New York, USA: Academic Press, 1978. Pp. 465-8. doi: 10.1016/B978-0-12-322650-1.50090-4.

25. Glauche I, Moore K, Thielecke L, Horn K, Loeffler M, Roeder I. Stem cell proliferation and quiescence: Two sides of the same coin. PLoS Comput Biol 2009; 5:e1000447. doi: 10.1371/journal. pcbi.1000447.
26. Yahata T, Takanashi T, Muguruma Y, Ibrahim AA, Matsuzawa H, Uno T, et al. Accumulation of oxidative DNA damage restricts the self-renewal capacity of human hematopoietic stem cells. Blood 2011; 118:2941-50. doi: 10.1182/blood-2011-01-330050.

27. Beerman I, Seita J, Inlay MA, Weissman IL, Rossi DJ. Quiescent hematopoietic stem cells accumulate DNA damage during aging that is repaired upon entry into cell cycle. Cell Stem Cell 2014; 15:37-50. doi: 10.1016/j.stem.2014.04.016.

28. Seita J, Weissman IL. Hematopoietic stem cell: Self-renewal versus differentiation. Wiley Interdiscip Rev Syst Biol Med 2010; 2:640-53. doi: 10.1002/wsbm.86.

29. Altinoz E, Turkoz Y. The protective role of N-acetylcysteine against acrylamide-induced genotoxicity and oxidative stress in rats. Gene Ther Mol Biol 2014; 16:35-43.

30. Richardson C, Yan S, Vestal CG. Oxidative stress, bone marrow failure, and genome instability in hematopoietic stem cells. Int J Mol Sci 2015; 16:2366-85. doi: 10.3390/ijms16022366.

31. Tothova Z, Kollipara R, Huntly BJ, Lee BH, Castrillon DH, Cullen DE, et al. FoxOs are critical mediators of hematopoietic stem cell resistance to physiologic oxidative stress. Cell 2007; 128:325-39. doi: 10.1016/j.cell.2007.01.003. 